\title{
How varying CD4 criteria for treatment initiation was associated with mortality of HIV-patients? A retrospective analysis of electronic health records from Andhra Pradesh, India
}

\author{
Ram Bajpai ${ }^{1,2}$, Himanshu K \\ Chaturvedi' ${ }^{2}$, Josip Car ${ }^{3,4}$ \\ ${ }^{1}$ School of Primary Community \\ and Social Care, Keele University, \\ Newcastle-Under-Lyme, Staffordshire, \\ UK \\ ${ }^{2}$ National Institute of Medical Statistics, \\ Indian Council of Medical Research, \\ New Delhi, India \\ ${ }^{3}$ Centre for Population Health Sciences, \\ Lee Kong Chian School of Medicine, \\ Nanyang Technological University, \\ Singapore \\ ${ }^{4}$ Global eHealth Unit, Department of \\ Primary Care and Public Health, School \\ of Public Health, Imperial College \\ London, London, UK
}

\begin{abstract}
Background HIV treatment and care services were scaled up in 2007 in India with objective to increase HIV-care coverage. CD4 count based criteria was mainly used for treatment initiation with increasing threshold in later years. Therefore, this paper aimed to evaluate the survival by varying CD4 criteria for antiretroviral treatment (ART) initiation among of HIV-positive patients, and independent factors associated with the mortality.
\end{abstract}

Methods This retrospective cohort study included 127949 HIV-positive patients aged $\geq 15$ years, who initiated ART between 2007 and 2013 in Andhra Pradesh state, India. The patient's demographic and clinical characteristics were extracted from the patient's health records from electronic Computerized Management Information System Software (CMIS). Incidence of mortality/100 person-years was calculated for CD4 and treatment initiation categories. Kaplan-Meier and multivariable Cox-regression analyses were used to explore the association.

Results Median CD4 count was 172 (inter-quartile range $(I Q R)=102-240$ ) at the time of treatment initiation, and $19.3 \%$ of them had $\leq 100$ CD 4 count. Incidence of mortality for the period 2007-08 (CD4 $\left.\leq 200 \mathrm{cells} / \mathrm{mm}^{3}\right)$ was $8.5 / 100$ person-years compared to 6.4/100 person-years at risk for the period 2012 onwards $\left(C D 4 \leq 350\right.$ cells $\left./ \mathrm{mm}^{3}\right)$. Earlier thresholds for treatment initiation showed higher risk of mortality (2007-08 (CD4 $\left.\leq 200 \mathrm{cells} / \mathrm{mm}^{3}\right)$, adjusted hazard ratio (HR): 1.86, 95\% confidence interval (CI): 1.68-2.07; 2009-11 (CD4 $\leq 250$ cells/ $\left.\left.\mathrm{mm}^{3}\right), \mathrm{HR}=1.67,95 \% \mathrm{CI}=1.51-1.85\right)$ compared to 2012 onwards $(\mathrm{CD} 4 \leq 350$ cells $/ \mathrm{mm}^{3}$ ) criteria for treatment initiation.

Conclusions Increasing CD4 threshold for treatment initiation over time was independently associated with lower risk of mortality. More efforts are required to detect and treat early, monitoring of follow-ups, promote health education to improve ART adherence, and provide supportive environment that encourages HIV-infected patients to disclose their HIV status in confidence.

\section{Correspondence to:}

Ram Bajpai, PhD

School of Primary Community and

Social Care

Keele University

Newcastle-Under-Lyme

Staffordshire, ST5 5BG

UK

r.bajpai@keele.ac.uk
India formed an AIDS Task Force under the Indian Council of Medical Research (ICMR) to respond HIV/AIDS challenge after the detection of first AIDS case in 1986 [1]. Since then, HIV infections have been reported in all states and union territories. Further, to manage the HIV programme and its implementation, an autonomous National AIDS Control Organisation (NACO) was set up under the ministry of Health [2]. India launched a free antiretroviral treatment (ART) programme in 2004, and more than 400 ART centres are providing HIV care across the nation $[3,4]$. 
The ART services were scaled up at national level in 2007 with objective to increase HIV-care coverage. A new treatment criterion (CD4 count $\leq 200$ cells $/ \mathrm{mm}^{3}$ or HIV clinical stage III/IV irrespective of CD4 count, including coinfections such as tuberculosis) for ART initiation was adapted [5]. The CD4 criteria for ART initiation was further modified in 2009 to $\leq 250$ cells $/ \mathrm{mm}^{3}$ and to $\leq 350$ cells $/ \mathrm{mm}^{3}$ in 2012, as recommended by the Joint United Nations Programme on HIV/AIDS (UNAIDS) [6]. Addition to treatment, ART centres also facilitate follow-up monitoring, screening for opportunistic infections, and counselling. The 2013 World Health organisation (WHO) ART guidelines strongly recommended initiating ART for all adults PLHIV with a CD4 count $\leq 500$ cells $/ \mathrm{mm}^{3}$, regardless of WHO clinical stage [7]. Early start of ART is associated with reduced risk of AIDS progression or death, TB, other coinfections and increased likelihood of immune recovery [8-10]. Additionally, evidence from a randomized controlled trial indicated that earlier ART can significantly reduce the risk of HIV to HIV-negative sexual partners in heterosexual couples [11]. The WHO database suggests nearly two-third (60\%) of the fifty-eight HIV-focused countries had adopted the CD4 threshold of $\leq 500$ cells $/ \mathrm{mm}^{3}$ for initiating ART, and 7\% moved the CD4 threshold to $>500$ cells $/ \mathrm{mm}^{3}$ by June 2014 [12]. Although the median CD4 count at the time of ART initiation is progressively increasing, however, it remained significantly lower than 350 cells $/ \mathrm{mm}^{3}$ in almost all settings $[13,14]$. Despite the considerable increase in the number of PLHIVs in India accessing ART from $17 \%$ in 2007 to $52 \%$ in 2013, ART coverage of people eligible for treatment is still low [6,15]. The success of the ART program depends upon proper monitoring for drug adherence, timely presentation and CD4 investigation, as well as motivation for pre-ART cases for on-time visits to the nearest ART centre for their further assessment to prevent the progression and transmission of HIV [6,12-17].

Several single centre-based studies have been conducted in India to look for demographic and clinical factors (such as higher age, male gender, clinical staging III/IV, lesser bodyweight, and low CD4 count etc.) associated with the early mortality [18-21]. However, limited studies have been published at the state level from India to reconfirm these factors. Therefore, the main objective of this study was to explore the survival by varying CD4 criteria of treatment initiation, and the secondary objective was to explore the independent factors associated with the mortality.

\section{METHODS}

\section{Study Design, period and inclusion}

This retrospective analysis included all registered adult (aged $\geq 15$ years) HIV/AIDS patients, who initiated ART treatment between January 2007 and December 2013 in undivided Andhra Pradesh state. The patient's demographic and clinical characteristics were extracted from the patient's health records from electronic Computerized Management Information System Software (CMIS). We excluded data from the analysis if the patient initiated their treatment elsewhere and registered in Andhra Pradesh, pre-ART cases, ART initiation date was missing, ART started in Andhra Pradesh but later transferred out to other states, and if the status was unknown at the end of the study period.

\section{State profile}

Andhra Pradesh (undivided; as it was divided into Andhra Pradesh and Telangana in 2014) is one of the highly populated southern region state in India. According to the national Census 2011, Andhra Pradesh had 84.6 million population, with a total area of $275045 \mathrm{~km}^{2}$ and population density of $308 / \mathrm{km}^{2}$, literacy rate of 67\% (male: 74.9\%; female: 58.7\%), and the sex ratio of 993 females per 1000 males. Administratively, Andhra Pradesh was divided into 23 districts that further divided into 1127 revenue divisions. The state has a vast network of public health facilities, including 20 district hospitals, 56 area hospitals, 117 community health centres, 10 specialty hospitals, and 25 civil dispensaries [22].

\section{The HIV detection, treatment and burden in Andhra Pradesh}

As of December 2014, the state had 1869 integrated and counselling testing centres (ICTCs), including prevention of parent-to-child treatment (PPTCT) centres, 286 government recognized blood banks, and 274 sexually transmitted disease (STD) clinics [23]. There were 56 ART and 161 Link ART centres functional in the state providing free first and second line HIV treatments. The state also had 40 community care centres (CCCs) with the primary duty of counselling to HIV-patients and motivating them to enrol to the HIV programme $[3,23]$. ART centres primarily located at district hospitals and Link ART centres at sub-district level. According to 2012 estimates, Andhra Pradesh had the second highest HIV prevalence 
$(0.75 \%)$ in the age group of $15-49$ years after Manipur state (1.22\%); however, declined from the 2007 08 estimate. It remained one of the six high prevent states in India with the highest number of PLHIVs $(n=419000)$ accounting for nearly $20 \%$ of total HIV/AIDS cases in the country. The estimated cumulative deaths due to AIDS-related illnesses were highest in Andhra Pradesh (approximately 31000 ) in 2011 that declined from 46000 deaths in 2007 [3,23].

\section{Enrolment of patients to HIV care}

Once an HIV-positive individual reached to an ART centre with an ICTC report, s/he were registered in the pre-ART register for HIV care. Furthermore, demographic details and other relevant information were also recorded in the patient treatment record (also called White Card) and a Green Book was issued. Patients were advised to enrol at the nearest ART centre to their current place of residence to ensure proper adherence to treatment. S/he was re-counselled for implications of being HIV-positive, availability of treatment, positive living, nutrition, and positive prevention, etc. The early testing of their spouse/partner and children was encouraged. Recently detected persons were kept under the supervision of a care coordinator to determine whether a HIV-positive person was treated in the same manner as any other patients at the centre, without any discrimination. Furthermore, the patient was referred to a concerned doctor who conduct a detailed medical examination for WHO clinical staging, opportunistic infections (OIs) and other relevant clinical examinations. Based on the clinical findings, the HIV treatment was initiated as per the NACO guidelines described in the Table S1 in the Online Supplementary Document [5].

\section{Follow-ups and primary event}

The primary event of interest was the death of the patients. The date of death for all HIV-infected patients who died from all causes during the study period while on antiretroviral treatment was recorded. Patients missing their follow-up visits for more than three months were counted as lost to follow-up, and the date of the last registered follow-up visit was recorded as the date of follow-up loss. ART for HIV-infected patient who were transferred to another ART centre were recorded as transferred-out cases, and their dates of transfer-out were also recorded. Similarly, patients received medical advice was recorded as on medical advice and their dates of medical advice were also recorded [5].

\section{Study variables}

Patients' baseline demographic, program-related information and clinical characteristics data were collected. Baseline demographic characteristics included, age (15-24 years, 25-34 years, 35-44 years, and $>45$ years), sex (male/female), education (no formal education and formal education), marital status (single/married), and employment (employed or not employed). Time-period was divided according to the CD4 criteria for treatment initiation (ie, $\leq 200$ cells $/ \mathrm{mm}^{3}$ in $2007-2008, \leq 250$ cells $/ \mathrm{mm}^{3}$ in $2009-2011$ and $\leq 350$ from 2012 onwards). The HIV surveillance program-related information included date of ART initiation, follow-up status, and last date of ART centre visit. Clinical characteristics at the time of ART initiation included bodyweight ( $<45 \mathrm{~kg}, 45-60 \mathrm{~kg}$ and $>60 \mathrm{~kg}$ ), WHO clinical stage (I, II, III, and IV), and CD4 count ( $<100$ cells $/ \mathrm{mm}^{3}, 101-200$ cells $/ \mathrm{mm}^{3}, 201-250$ cells $/ \mathrm{mm}^{3}, 251-350$ cells $/ \mathrm{mm}^{3}, 351-500$ cells $/ \mathrm{mm}^{3}$ and $>500$ cells $/ \mathrm{mm}^{3}$ ). We presented missing data as a separate category in each variable and did not impute any value to figure out their characteristics. Imputation was not considered sensible in this case as data were unlikely to be missing at random.

\section{Statistical analysis}

The data were summarised numerically, in the form of percentages for categorical variables. Mean \pm standard deviations (SD) or median with interquartile range (IQR) were used to present quantitative data. Mortality density per 100 person-years was calculated for various CD4 categories and ART criteria years. The Kaplan-Meier (KM) method was used to estimate survival after ART initiation, and the log-rank test was used to determine statistical differences between survival rates in subgroups of the variable $[24,25]$. Univariable and multivariable Cox-regression analytical methods were applied to model predictors of mortality following treatment initiation [26]. The unadjusted and adjusted hazard ratios (HRs) with 95\% confidence intervals (CIs) were estimated. We evaluated departure from the proportional hazard assumption for Cox-regression by tests of Schonefild's residual and graphical inspection of log-log plots, and all the predictor variables satisfied the criterion of being asymptotic [24]. Data were analysed using Stata for Windows (version 14.0, StataCorp, College Station, TX, USA) software. The two-sided $P$-value $<0.05$ was considered as the level of significance. 


\section{Data access permission and ethical statement}

Individual level anonymised PLHIV data access permission was granted by NACO for undivided Andhra Pradesh under a data sharing scheme with national data analysis plan (NDAP) at phase I for policy making in high prevalent states (vide letter No. z-19019/1/2013-NACO(SIMU)). Data were made available to the first author for his PhD research by NACO for secondary data analysis, and it has been approved by the internal ethics committee. Individual consent was taken the affiliated organisations of NACO during the data collection and therefore, no additional consent was required in this study.

\section{RESULTS}

\section{Patient characteristics}

The baseline patient characteristics according to treatment initiation (based on CD4 criterion) of adult HIV-positive patients on ART are summarised in Table 1. Overall, $14.4 \%$ deaths were recorded during the study period with high proportion within the first year of treatment start $(84.8 \% ; 15566 / 18,362)$. Reported lost to follow up was $17.9 \%$ during 2007-08 that significantly decreased $(P<0.01)$ to $6.9 \%$ in 2012 onwards. The median age was 34 years, $45.9 \%$ females, $45.7 \%$ had formal education, $59.4 \%$ were employed and $68 \%$ were married. The median CD4 count was 172 (IQR 102-240) cells $/ \mathrm{mm}^{3}$ at the time of ART initiation that consistently increased over time (Figure S1 in the Online Supplementary Document).

Table 1. Demographic and clinical characteristics of HIV positive patients on antiretroviral treatment registered during $2007-11$ in undivided Andhra Pradesh, India

\begin{tabular}{|c|c|c|c|c|}
\hline \multirow[t]{2}{*}{ Backeround PROFILE } & \multirow[t]{2}{*}{$\begin{array}{l}\text { INCLUDED IN THE ANAL- } \\
\text { YSIS ( } \mathrm{N}=127949 \text { ) }\end{array}$} & \multicolumn{3}{|c|}{ Period of treatment criterion for initiation based on CD4 COUNt } \\
\hline & & $\begin{array}{c}2007-08 \\
(n=39542)\end{array}$ & $\begin{array}{l}2009-2011 \\
(\mathrm{n}=79776)\end{array}$ & $\begin{array}{c}2012 \text { onwards } \\
\quad(\mathrm{n}=8631)\end{array}$ \\
\hline \multicolumn{5}{|l|}{ Patient characteristics } \\
\hline Age (in years) at ART initiation, median (IQR) & $34(29-40)$ & $33(28-39)$ & $35(29-40)$ & $33(28-40)$ \\
\hline Female, (n, \%) & $58677(45.9)$ & $16929(42.8)$ & $36902(46.3)$ & $4846(56.1)$ \\
\hline Patients who had formal education, (n, \%) & $58462(45.7)$ & $19528(49.4)$ & $35292(44.2)$ & $3642(42.2)$ \\
\hline Currently working, (n, \%) & $75989(59.4)$ & $28530(72.2)$ & $42898(53.8)$ & $4561(65.8)$ \\
\hline Body-weight $<45 \mathrm{~kg}$ at the time of ART initiation, (n, \%) & $42327(33.1)$ & $13232(33.5)$ & $26831(33.6)$ & $2264(26.2)$ \\
\hline Married/ cohabiting, (n, \%) & $87057(68.0)$ & $27128(68.6)$ & $53752(67.4)$ & $6177(71.6)$ \\
\hline CD4 cell count (cells $/ \mathrm{mm}^{3}$ ) at the time ART initiation, median (IQR) & $172(102-240)$ & $144(85-204)$ & $178(107-242)$ & $278(200-333)$ \\
\hline \multicolumn{5}{|l|}{ CD4 count category (cells/mm3), (n, \%): } \\
\hline$\leq 100$ & $24705(19.3)$ & $98,58(24.9)$ & $14340(18.0)$ & $507(5.9)$ \\
\hline $101-200$ & $37029(28.9)$ & $13491(34.1)$ & $22213(27.8)$ & $1325(15.4)$ \\
\hline $201-250$ & $17849(14.0)$ & $4517(11.4)$ & $12301(15.4)$ & $1031(11.9)$ \\
\hline $251-350$ & $12512(9.8)$ & $2212(5.6)$ & $7058(8.8)$ & $3242(37.6)$ \\
\hline $351-500$ & $5189(4.1)$ & $982(2.5)$ & $3549(4.4)$ & $658(7.6)$ \\
\hline $501+$ & $4264(3.3)$ & $701(1.8)$ & $3067(3.8)$ & $496(5.7)$ \\
\hline Missing & $26401(20.6)$ & $7781(19.7)$ & $17248(21.6)$ & $1372(15.9)$ \\
\hline \multicolumn{5}{|l|}{ WHO clinical stage at the time of ART initiation, (n, \%): } \\
\hline I & $19293(15.0)$ & $3613(9.1)$ & $12802(16.0)$ & $2878(33.3)$ \\
\hline II & $50066(39.1)$ & $12952(32.8)$ & $33702(42.2)$ & $3412(39.5)$ \\
\hline III & $37173(29.1)$ & $14797(37.4)$ & $21505(27.0)$ & $871(10.1)$ \\
\hline IV & $3524(2.8)$ & $1309(3.3)$ & $2116(2.7)$ & $99(1.1)$ \\
\hline Missing & $17893(14.0)$ & $6871(17.4)$ & $9651(12.2)$ & $1371(15.9)$ \\
\hline \multicolumn{5}{|l|}{ Program context } \\
\hline Number of ART centres & 56 & 31 & 45 & 56 \\
\hline Number of districts covered & 25 & 22 & 23 & 25 \\
\hline Number of people registered for ART & 291151 & 103946 & 187205 & $-*$ \\
\hline Recorded adherence ( $\geq 95 \%)$ to ART, $(\%)$ & 89.5 & 90.3 & 89.3 & 86.8 \\
\hline Total recorded deaths, (n, \%) & $18362(14.4)$ & $7061(17.9)$ & $10902(13.7)$ & $399(4.6)$ \\
\hline Deaths within lst year of ART start, (n, \%) & $15566(12.2)$ & $5618(14.2)$ & $9563(12.0)$ & $385(4.5)$ \\
\hline Recorded lost to follow up, (n, \%) & $16536(12.9)$ & $6992(17.7)$ & $8953(11.2)$ & $591(6.9)$ \\
\hline
\end{tabular}

ART - antiretroviral treatment

*All these HIV-patients were registered between 2007 and 2011. 


\section{Person-years and survival analysis}

The study cohort contributed a total of 208301 person-years at risk during the study period as presented in Table 2. Overall mortality density was $8.8(95 \% \mathrm{CI}=8.7-8.9)$ per 100 person-years at risk.

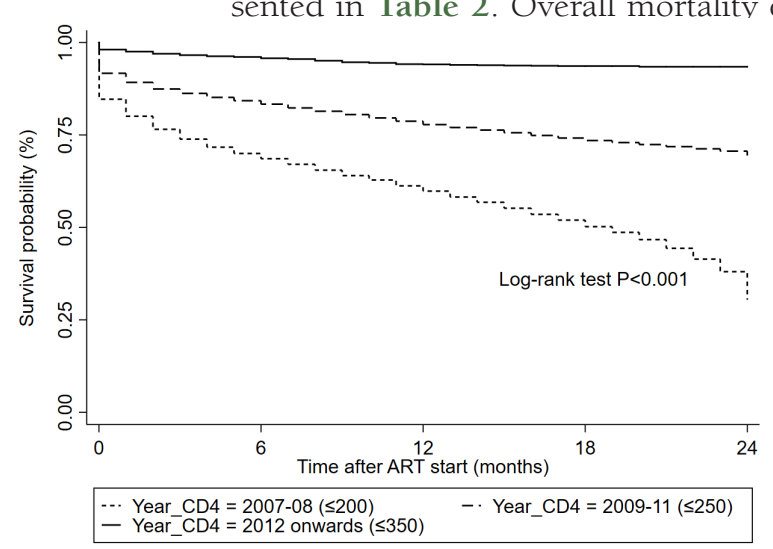

Figure 1. Survival probabilities at 24 months after ART initiation by varying CD4 criteria for treatment initiation.
The incidence of mortality was reported higher with the earlier treatment initiation periods $(8.5$ and 11.0 per 100 person-years in 2007-08 and 2009-11 respectively) compared to 6.4 per 100 person-years from 2012 onwards. The mortality incidence was also consistently decreased when CD4 count increased (13.2/100 person-years for CD4 $\leq 100$ to 2.0/100 person-years for CD4 > 500). Overall mean survival during the study period was 66.7 (95\% CI=66.5-67.0) months and significantly different between CD4 subgroups (Figures S2 \& S3 in the Online Supplementary Document). A twenty-four months survival was recorded to $96.1 \%$ who started their treatment with the CD4 count $\leq 350$ cells $/ \mathrm{mm}^{3}$ treatment initiation criteria in 2012 onwards compared to $59.8 \%$ survival with CD4 count $\leq 200$ cells $/ \mathrm{mm}^{3}$ criteria in 2007-08 (Figure 1).

\section{Risk of mortality with varying CD4 levels over time}

The effect of varying CD4 cell count categories on the risk of dying in first year of treatment initiation over time is presented in Table 3. Higher rates of mortality (11.3\% to 18.6\% for 2007-08 period; and $11.7 \%$ to $21.1 \%$ for $2009-11$ period) have been reported compared to $6.9 \%-11.4 \%$ from 2012 onwards when patient level CD4 count $\leq 200$ cells $/ \mathrm{mm}^{3}$. Furthermore, multivariable Cox regression was used to estimate adjusted hazard ratios for 2007-08 (HR range $=1.04-2.36)$ and (HR range $=0.64-1.73$ ) 2009-11 to explored the trend of risk in different CD4 levels compared to 2012 onwards category. This analysis clearly indicated higher risk of mortality within the first year of treatment start was associated with older treatment initiation criteria (on average 60\% higher risk to 2007-08 and 22\% higher risk to 2009-11 compared to 2012 onwards).

\section{Factors associated with mortality}

The unadjusted and adjusted analysis showed the associated predictors of mortality within the first year of treatment initiation among adult HIV-infected patients in Table 4. The risk of mortality within the first-year of treatment initiation was significantly associated with older age ( $\geq 45$ years, HR $=1.4,95 \%$ $\mathrm{CI}=1.27-1.71)$, male gender $(\mathrm{HR}=1.56,95 \% \mathrm{CI}=1.51-1.63)$, with no formal education $(\mathrm{HR}=1.16,95 \%$ $\mathrm{CI}=1.12-1.20)$ and working by occupation $(\mathrm{HR}=1.17,95 \% \mathrm{CI}=1.13-1.21)$. Further, patients with WHO clinical stage IV had a 1.67-fold increased risk of mortality compared to those at stage I. The likelihood

Table 2. Mortality distribution among the HIV-positive patients who had initiated treatment over time with different treatments criteria

\begin{tabular}{|c|c|c|c|c|c|}
\hline BaCKGROUND VARIabies & $\begin{array}{l}\text { OVERALL DEATHS } \\
\text { DURING STUDY }\end{array}$ & $\begin{array}{l}\text { DeATHS WITHII } \\
12 \text { mo }(\%)\end{array}$ & $\begin{array}{l}\text { Crude mortaltiy raite } \\
\text { (per } 100 \text { registrations) }\end{array}$ & $\begin{array}{c}\text { TotAL PER- } \\
\text { SON-YEARS AT RISK }\end{array}$ & $\begin{array}{l}\text { INCIDENCE MORTALITY RAIES PER } 100 \\
\text { PERSON-YEARS* (95\% CI) }\end{array}$ \\
\hline \multicolumn{6}{|c|}{ CD4 count (cells/mm³) (across the years) } \\
\hline$\leq 100$ & 5640 & $4914(19.9)$ & 22.8 & 42657 & $13.2(12.8-13.5)$ \\
\hline $101-200$ & 5117 & $4222(11.4)$ & 13.8 & 62508 & $8.2(7.9-8.4)$ \\
\hline $201-250$ & 1542 & $1238(6.9)$ & 8.6 & 27386 & $5.6(5.3-5.9)$ \\
\hline $251-350$ & 804 & $647(5.2)$ & 6.4 & 18272 & $4.4(4.1-4.7)$ \\
\hline $351-500$ & 204 & $151(2.9)$ & 3.9 & 7504 & $2.7(2.3-3.1)$ \\
\hline $500+$ & 124 & $93(2.2)$ & 2.9 & 6106 & $2.0(1.6-2.4)$ \\
\hline Missing & 4931 & $4301(16.3)$ & 18.7 & 42539 & $11.6(11.2-11.9)$ \\
\hline \multicolumn{6}{|l|}{ ART criteria year: } \\
\hline 2007-08 (CD4 $\leq 200$ cells/mm³) & 7061 & $5618(14.2)$ & 17.9 & 82972 & $8.5(8.3-8.7)$ \\
\hline 2009-11 (CD4 $\leq 250$ cells $\left./ \mathrm{mm}^{3}\right)$ & 10902 & $9563(12.0)$ & 13.7 & 99467 & $11.0(9.9-11.2)$ \\
\hline $2012\left(\mathrm{CD} 4 \leq 350\right.$ cells $\left./ \mathrm{mm}^{3}\right)$ & 399 & $385(4.5)$ & 4.6 & 6278 & $6.4(5.7-7.0)$ \\
\hline Combined & 18362 & $15566(12.2)$ & 14.4 & 2871782 & $8.8(8.7-8.9)$ \\
\hline
\end{tabular}

ART - antiretroviral treatment, CI - confidence interval

*Calculated as overall deaths divided by total person-years at risk during the study period. 
Table 3. Risk of mortality in the first year of treatment initiation with varying CD4 levels in HIV-positive individuals Patient CD4 LeVELS AND Year OF Change In ELIGBBITY FOR TREATMENT

$\mathrm{CD} 4 \leq 100$ :

\begin{tabular}{|c|c|c|c|}
\hline 2007-08 & 18.6 & $1.47(1.13-1.90)$ & $1.38(1.06-1.80)$ \\
\hline 2009-11 & 21.1 & $1.67(1.29-2.17)$ & $1.66(1.28-2.15)$ \\
\hline 2012 (ref) & 11.4 & 1 & 1 \\
\hline \multicolumn{4}{|c|}{ CD4 101-200: } \\
\hline 2007-08 & 11.3 & $1.41(1.14-1.75)$ & $1.34(1.08-1.65)$ \\
\hline 2009-11 & 11.7 & $1.47(1.20-1.82)$ & $1.17(1.17-1.77)$ \\
\hline 2012 (ref) & 6.9 & 1 & 1 \\
\hline \multicolumn{4}{|c|}{ CD4 201-250: } \\
\hline 2007-08 & 8.4 & $1.91(1.37-2.65)$ & $1.73(1.24-2.41)$ \\
\hline 2009-11 & 6.6 & $1.52(1.10-2.30)$ & $1.46(1.06-2.01)$ \\
\hline 2012 (ref) & 3.8 & 1 & 1 \\
\hline \multicolumn{4}{|c|}{ CD4 251-350: } \\
\hline 2007-08 & 8.1 & $2.51(1.95-3.24)$ & $2.36(1.81-3.07)$ \\
\hline 2009-11 & 5.4 & $1.68(1.33-2.12)$ & $1.61(1.27-2.03)$ \\
\hline 2012 (ref) & 2.7 & 1 & 1 \\
\hline \multicolumn{4}{|c|}{ CD4 351-500: } \\
\hline $2007-08$ & 5.3 & $1.79(1.02-3.14)$ & $1.72(0.97-3.04)$ \\
\hline 2009-11 & 2.3 & $0.77(0.45-1.31)$ & $0.75(0.44-1.28)$ \\
\hline 2012 (ref) & 2.4 & 1 & 1 \\
\hline \multicolumn{4}{|l|}{ CD4 501+: } \\
\hline 2007-08 & 3.1 & $1.02(0.51-2.07)$ & $1.04(0.51-2.12)$ \\
\hline 2009-11 & 1.9 & $0.64(0.34-1.18)$ & $0.64(0.35-1.20)$ \\
\hline 2012 (ref) & 2.4 & 1 & 1 \\
\hline \multicolumn{4}{|c|}{ CD4 - missing: } \\
\hline $2007-08$ & 20.8 & $3.69(2.95-4.61)$ & $3.53(2.81-4.41)$ \\
\hline 2009-11 & 15.1 & $2.46(1.97-3.06)$ & $2.29(1.84-2.86)$ \\
\hline 2012 (ref) & 5.9 & 1 & 1 \\
\hline
\end{tabular}

Ref - reference category, HR - hazard ratio, CI - confidence interval

*Adjusted for socio-demographic (age, sex, education, marital status, and employment) and clinical (bodyweight and WHO clinical stage) characteristics.

of death among those with a baseline CD4 count of $\leq 100$ cells $/ \mathrm{mm}^{3}$ increased to 9-fold (HR $=9.44,95 \%$ $\mathrm{CI}=7.78-11.59$ ), compared to the patients with CD4 count $>500$ cells $/ \mathrm{mm}^{3}$.

\section{DISCUSSION}

The ART scaling-up service has resulted greater coverage of HIV-patients at the early stages. Our findings clearly indicate higher incidence of mortality for earlier treatment initiation criteria $-8.5 / 100$ persons-years for 2007-08 period $\left(C D 4 \leq 200\right.$ cells $\left./ \mathrm{mm}^{3}\right)$, and 11.0/100 person-years for 2009-11 period $(C D 4 \leq 250$ cells $\left./ \mathrm{mm}^{3}\right)$ - compared to 2012 onwards $\left(\mathrm{CD} 4 \leq 350\right.$ cells $\left./ \mathrm{mm}^{3}\right)$ criteria. Further, the overall excess risk of death was $84 \%(\mathrm{HR}=1.84,95 \% \mathrm{CI}=1.66-2.04)$ for $2007-08$ period $\left(\mathrm{CD} 4 \leq 200 \mathrm{cells} / \mathrm{mm}^{3}\right)$, and $61 \%$ $(\mathrm{HR}=1.61,95 \% \mathrm{CI}=1.46-1.79)$ for 2009-11 period $\left(\mathrm{CD} 4 \leq 250 \mathrm{cells} / \mathrm{mm}^{3}\right)$ compared to 2012 onwards $\left(C D 4 \leq 350\right.$ cells $\left./ \mathrm{mm}^{3}\right)$ criteria. These findings are in agreement with other studies published from resource-limited settings $[9,27,28]$. An increased level of CD4 count is always linked with a decreased risk of a new AIDS event or death [29-31]. Furthermore, a multinational study showed that early start of ART could increase life expectancy of HIV-positive persons to the general population [29-32].

Decentralisation of HIV care delivery has increased population coverage and encouraged early access to ART centres with lower travel costs compared to hospitals $[29,30]$. Patients who approach ART centre at their early stage could delay complex disease conditions due to convenient and easier access to HIV care facility. Therefore, decentralisation of ART services seems to be associated with earlier presentation to HIV care, which might provide opportunity to many patients to initiate early treatment during the disease progression. Increasing numbers of patients have been shown an inclination to start ART in the early stages $[4,6]$. 
Table 4. Factors associated with mortality after antiretroviral treatment initiation by multivariable Cox regression analysis

\begin{tabular}{|c|c|c|c|c|}
\hline \multirow[b]{2}{*}{ Patient CHARACteristics } & \multicolumn{2}{|c|}{ WITHIN FIRST YeAR Of ART INITIATION } & \multicolumn{2}{|c|}{ WITHIN THE OVERALL STUDY PERIOD } \\
\hline & $\begin{array}{l}\text { Unadjusted HR } \\
\quad(95 \% \mathrm{CI})\end{array}$ & $\begin{array}{c}\text { Adjusted HR } \\
(95 \% \mathrm{CI})\end{array}$ & $\begin{array}{l}\text { Unadjusted HR } \\
\qquad(95 \% \mathrm{CI})\end{array}$ & $\begin{array}{c}\text { Adjusted HR } \\
(95 \% \mathrm{CI})\end{array}$ \\
\hline \multicolumn{5}{|l|}{ Age (categorical): } \\
\hline $15-24(\mathrm{ref})$ & 1 & 1 & 1 & 1 \\
\hline $25-34$ & $1.28(1.19-1.37)$ & $1.22(1.13-1.30)$ & $1.28(1.21-1.37)$ & $1.22(1.14-1.30)$ \\
\hline $35-44$ & $1.55(1.44-1.66)$ & $1.39(1.30-1.49)$ & $1.54(1.44-1.64)$ & $1.38(1.29-1.47)$ \\
\hline $45+$ & $1.85(1.72-1.99)$ & $1.57(1.46-1.69)$ & $1.85(1.73-1.98)$ & $1.58(1.48-1.69)$ \\
\hline \multicolumn{5}{|l|}{ Sex: } \\
\hline Male & $1.67(1.61-1.72)$ & $2.05(1.97-2.13)$ & $1.69(1.64-1.74)$ & $2.07(2.00-2.15)$ \\
\hline Female (ref) & 1 & 1 & 1 & 1 \\
\hline No formal education & $1.10(1.06-1.13)$ & $1.04(1.01-1.08)$ & $1.10(1.07-1.13)$ & $1.06(1.03-1.09)$ \\
\hline Formal education (ref) & 1 & 1 & 1 & 1 \\
\hline \multicolumn{5}{|l|}{ Marital status: } \\
\hline Single (ref) & 1 & 1 & 1 & 1 \\
\hline Married/Live-in & $1.02(0.99-1.06)$ & $0.90(0.87-0.93)$ & $1.04(1.00-1.07)$ & $0.90(0.87-0.93)$ \\
\hline \multicolumn{5}{|l|}{ Occupation } \\
\hline Working & $1.19(1.15-1.23)$ & $1.18(1.14-1.22)$ & $1.18(1.14-1.22)$ & $1.17(1.13-1.20)$ \\
\hline Not working (ref) & 1 & 1 & 1 & 1 \\
\hline \multicolumn{5}{|l|}{ Weight $(\mathrm{kg})$ : } \\
\hline$<45$ & $3.82(3.52-4.15)$ & $4.09(3.76-4.45)$ & $3.48(3.23-3.74)$ & $3.83(3.56-4.13)$ \\
\hline $45-60$ & $1.86(1.71-2.02)$ & $1.79(1.64-1.94)$ & $1.80(1.67-1.93)$ & $1.75(1.62-1.88)$ \\
\hline $61+(\mathrm{ref})$ & 1 & 1 & 1 & 1 \\
\hline missing & $3.15(2.89-3.44)$ & $3.09(2.82-3.38)$ & $2.95(2.72-3.19)$ & $2.98(2.74-3.24)$ \\
\hline \multicolumn{5}{|l|}{ Treatment start period: } \\
\hline $2007-2008\left(\leq 200\right.$ cells $\left./ \mathrm{mm}^{3}\right)$ & $2.96(2.67-3.28)$ & $1.68(1.51-1.87)$ & $3.11(2.81-3.44)$ & $1.84(1.66-2.04)$ \\
\hline $2009-2011\left(\leq 250\right.$ cells $\left./ \mathrm{mm}^{3}\right)$ & $2.45(2.21-2.72)$ & $1.58(1.42-1.75)$ & $2.43(2.20-2.69)$ & $1.61(1.46-1.79)$ \\
\hline 2012 onwards $(\leq 350$ cells/mm³ $)(\mathrm{ref})$ & 1 & 1 & 1 & 1 \\
\hline \multicolumn{5}{|l|}{ CD4 count $\left(\right.$ cells $\left./ \mathrm{mm}^{3}\right)$} \\
\hline$\leq 100$ & $10.34(8.42-12.69)$ & $7.40(6.02-9.10)$ & $9.01(7.58-10.82)$ & $6.48(5.42-7.75)$ \\
\hline $101-200$ & $5.59(4.55-6.86)$ & $4.72(3.84-5.80)$ & $5.11(4.27-6.10)$ & $4.27(3.57-5.11)$ \\
\hline $201-250$ & $3.32(2.69-4.10)$ & $3.12(2.52-3.85)$ & $3.13(2.61-3.76)$ & $2.91(2.42-3.50)$ \\
\hline $251-350$ & $2.53(2.04-3.15)$ & $2.54(2.04-3.16)$ & $2.44(2.02-2.95)$ & $2.42(2.00-2.93)$ \\
\hline $351-500$ & $1.35(1.04-1.75)$ & $1.28(0.99-1.66)$ & $1.37(1.10-1.72)$ & $1.29(1.04-1.62)$ \\
\hline $501+(\mathrm{ref})$ & 1 & 1 & 1 & 1 \\
\hline missing & $8.48(6.90-10.41)$ & $6.42(5.23-7.89)$ & $7.48(6.26-8.94)$ & $5.69(4.76-6.80)$ \\
\hline \multicolumn{5}{|l|}{ WHO clinical stage: } \\
\hline I (ref) & 1 & 1 & 1 & 1 \\
\hline II & $1.14(1.08-1.21)$ & $0.96(0.91-1.02)$ & $1.15(1.09-1.20)$ & $0.97(0.92-1.02)$ \\
\hline III & $1.59(1.50-1.68)$ & $1.19(1.13-1.26)$ & $1.55(1.48-1.63)$ & $1.17(1.12-1.23)$ \\
\hline IV & $3.32(3.06-3.59)$ & $2.02(1.87-2.19)$ & $3.15(2.92-3.39)$ & $1.96(1.82-2.11)$ \\
\hline missing & $1.44(1.36-1.54)$ & $0.99(0.92-1.06)$ & $1.42(1.34-1.50)$ & $0.97(0.91-1.04)$ \\
\hline
\end{tabular}

ART - antiretroviral treatment, HR - hazard ratio, CI - confidence interval, ref - reference category, WHO - World Health Organisation

This retrospective analysis showed $85 \%$ of the total deaths have been occurred within the first year of treatment start. This indicates majority of these patients were accessed ART at the later stage of their disease, and explained by the fact that more than one-third (38.4\%) of these patients had both CD4 cell count $\leq 200$ cells $/ \mathrm{mm}^{3}$ and WHO clinical stage III/IV at the time of treatment start. Other Indian $[9,16,18,19]$ and international [10,33-36] studies conducted in the other low- and middle-income countries confirmed similar findings. Several self-perceived personal (such as service delivery, financial, personal health perception, and logistical) and structural barriers may also play a significant role in delaying ART accessing at the earlier stage [37].

The CD4 count is an established indicator of the disease severity that directly related to the functional and immune status of a patient, and risk of early mortality among those with lower CD4 counts [38]. Our analysis also showed higher risk of mortality with CD4 count $\leq 350$ cell $/ \mathrm{mm}^{3}$. A study in Hong Kong showed 2.69-fold risk of death when they start treatment with a CD4 count $<100$ cells $/ \mathrm{mm}^{3}$ during the follow-up 
period [39]. Additionally, a study in South Korea showed that patients with CD4 cell count $<200$ cells/ $\mathrm{mm}^{3}$ had about 5-fold higher mortality than did those with $\geq 500$ cells $/ \mathrm{mm}^{3}$ [35]. The CD4 cell count is one of the key predictor of mortality, as confirmed by several other studies $[35,36,39]$ but some of studies did not show any association with mortality $[10,40]$. This may be partly explained by the way CD4 count measured (continuous or categorical), type of categorisation used, and number of events observed in different CD4 count subgroups, that could have made it statistically unreliable.

Males were more at risk for HIV-infection who probably acquired it from the high-risk population (such as female sex workers) and transmit to their female partner(s). Our findings are similar with other studies from under-developed nations $[41,42]$, but not all of them $[34,43]$. Females are regularly tested during the antenatal care visits or when their spouse show any symptoms leading to earlier diagnosis and treatment of HIV, which could be a reason for their decreased risk of mortality. Though, a gender-wise separate analysis in the same state indicated an increased risk of death in older females with the advanced clinical stages and lower CD4 counts [9]. This could be a result of social discrimination against females, awareness regarding HIV, and no direct health care facilities. Similar pattern was also observed in some previous studies from resource-limited settings $[21,40]$. These, differences may vary with geography and social structure of the society. Our analysis showed six years of mean survival after initiation of the antiretroviral treatment, which is alike with other studies $[21,43]$, although it remains lower than the developed nations $[8,39]$. Possible explanations include a lack of awareness, accessibility of the treatment, and social stigma.

The leading causes of HIV-related deaths are mainly due to immune reconstitution syndrome and opportunistic infections. According to a recent report, patients who start their HIV-treatment at late clinical stages (such as III/IV) are at an increased risk of dying [6]. Late presentation to HIV care could also be related to self-perceived barriers such as service delivery, finance, personal health perception etc. A study from South Africa showed forty-four percent participants had at least one barrier and twenty-four percent reported more than three barriers to care that increases excess mortality from fifty percent to eighty percent [37]. Late presentation, either at advanced stages of the disease or with very low CD4 counts, is alarmingly high in both developing and developed countries $[10,21,44]$. Delayed testing and presentation at HIV care centres is a consequence of the appearance of symptoms, while earlier diagnosis and presentation is the result of self-perceived risk or universal screening. Early disease stage presentation at ART centres will benefit to prevent the progression of AIDS complexity and increasing survival.

\section{Limitations}

There were several limitations in this study, and results may carefully be interpreted in the light of these limitations. The electronic database did not have information on causes of death, details of treatment regimen, incomplete data in several important variables, and opportunistic infections. Although these details were routinely entered in the ART registers. Several important variables such as haemoglobin, height and other clinical information were dropped from the analysis due to incomplete information in the electronic database. Additionally, lost to follow-up cases were intractable for outcome assessment and may have been at increased risk of dying. This study was retrospectively conducted; therefore, limitations of retrospective studies were also included in this study.

\section{CONCLUSIONS AND IMPLICATIONS}

In conclusion, this study compared the effect varying CD4 criteria for treatment initiation with mortality over time in Andhra Pradesh, India. Increased risk of mortality was found to be associated with the earlier CD4 cut-offs ( $\leq 200$ cells $/ \mathrm{mm}^{3}$ in 200708 , and $\leq 250$ cells $/ \mathrm{mm}^{3}$ in 2009-11) for treatment initiation compared to $\leq 350$ cells $/ \mathrm{mm}^{3}$ from 2012 onwards criteria. It indicates the requirement of more efficient and inclusive HIV programme to respond to the HIV epidemic in the state and country at large. As majority of the HIV-patients were died within the first year of treatment initiation, indicating more efforts are required to detect early, emphasis on regular follow-ups, promote health education to improve ART adherence, and provide supportive environment that encourages HIV-infected patients to disclose their HIV status in confidence. 


Acknowledgements: The authors would like to thank National AIDS Control Organisation (NACO) for sharing
ART surveillance data for PhD research under the National Data Analysis Plan (NACO/SIMU/NDAP/2015/02).
We presented analysis of secondary data and prior permission has been taken before its use. Therefore, no in-
formed consent was required. Some of the analysis findings have been presented at the RSS International Con-
ference 2019 at Belfast. The views discussed/expressed in this article are not of NACO or development part-
ners, rather it is completely, the understanding of the authors.
Funding disclosure: No public or private funding has been received by any authors of this study.
Contribution of authors: RB contributed to the conception, analysis, and interpretation of the data and to the
writing of the paper. HKC contributed to study conception and preparation of the draft paper. JC contributed
to interpretation of the data and to writing of the paper. All authors read and approved the final manuscript.
Conflicts of interest: The authors completed the ICMJE Unified Competing Interest form (available upon re-
quest from the corresponding author), and declare no conflicts of interest.
Additional material
Online Supplementary Document

1 Simoes EA, Babu PG, John TJ, Nirmala S, Solomon S, Lakshminarayana CS, et al. Evidence for HTLV-III infection in prostitutes in Tamil Nadu (India). Indian J Med Res. 1987;85:335-8. Medline:3623641

2 Panda S. The HIV/AIDS epidemic in India: an overview. Living with the AIDS virus: The epidemic and the response in India. New Delhi: Sage Publications; 20022002.

3 NACO. Technical reports: India HIV estimates New Delhi: National AIDS Control Organization (NACO), Ministry of Health \& Family Welfare, India, 2007-2012.

4 Pandey A, Sahu D, Bakkali T, Reddy D, Venkatesh S, Kant S, et al. Estimate of HIV prevalence and number of people living with HIV in India 2008-2009. BMJ Open. 2012;2: e000926. Medline:23028110 doi:10.1136/bmjopen-2012-000926

5 NACO. National Guidelines for Antiretroviral Therapy. New Delhi: National AIDS Control Organization (NACO), Ministry of Health \& Family Welfare, India, 2007-2012.

6 UNAIDS. World AIDS Day Reports. Geneva, Switzerland: Joint United Nations Programme on HIV/AIDS (UNAIDS), 2011-2014.

7 World Health Organization. Antiretroviral therapy (ART) guidelines. Geneva, Switzerland: WHO; 2013.

8 Cavanaugh JS, Shah NS, Cain KP, Winston CA. Survival among patients with HIV infection and smear-negative pulmonary tuberculosis - United States, 1993-2006. PLoS One. 2012;7:e47855. Medline:23110113 doi:10.1371/journal. pone.0047855

9 Bajpai R, Chaturvedi H, Jayaseelan L, Harvey P, Seguy N, Chavan L, et al. Effects of Antiretroviral Therapy on the Survival of Human Immunodeficiency Virus-positive Adult Patients in Andhra Pradesh, India: A Retrospective Cohort Study, 2007-2013. J Prev Med Public Health. 2016;49:394-405. Medline:27951632 doi:10.3961/jpmph.16.073

10 Bhatta L, Klouman E, Deuba K, Shrestha R, Karki DK, Ekstrom AM, et al. Survival on antiretroviral treatment among adult HIV-infected patients in Nepal: a retrospective cohort study in Far-western region, 2006-2011. BMC Infect Dis. 2013;13:604. Medline:24369908 doi:10.1186/1471-2334-13-604

11 Cohen MS, Chen YQ, McCauley M, Gamble T, Hosseinipour MC, Kumarasamy N, et al. Prevention of HIV-1 infection with early antiretroviral therapy. N Engl J Med. 2011;365:493-505. Medline:21767103 doi:10.1056/NEJMoal105243

12 WHO. UNICEF, UNAIDS. Global update on HIV treatment 2013: Results, impact and opportunities. Geneva, Switzerland: World Health Organisation (WHO), 2013.

13 Kiertiburanakul S, Boettiger D, Lee MP, Omar SF, Tanuma J, Ng OT, et al. Trends of CD4 cell count levels at the initiation of antiretroviral therapy over time and factors associated with late initiation of antiretroviral therapy among Asian HIV-positive patients. J Int AIDS Soc. 2014;17:18804. Medline:24598459 doi:10.7448/IAS.17.1.18804

14 Siedner MJ, Ng CK, Bassett IV, Katz IT, Bangsberg DR, Tsai AC. Trends in CD4 count at presentation to care and treatment initiation in sub-Saharan Africa, 2002-2013: a meta-analysis. Clin Infect Dis. 2015;60:1120-7. Medline:25516189

15 NACO. UNGASS India report: progress report on the declaration of commitment on HIV/AIDS. New Delhi, India: National AIDS Control Organisation (NACO), 2005.

16 Bajpai R, Raj Y, Jha U, Chaturvedi H, Pandey A. Demographic correlates of survival in adult HIV patients registered at ART centers in Andhra Pradesh, India: A retrospective cohort study. Public Health Research. 2014;4:31-8.

17 UNAIDS. How AIDS changed everything - MDG6: 15 years, 15 lessons of hope from the AIDS response. Geneva, Switzerland: Joint United Nations Programme on HIV/AIDS (UNAIDS), 2015.

18 Chakravarty J, Tiwary NK, Prasad SR, Shukla S, Tiwari A, Mishra RN, et al. Determinants of survival in adult HIV patients on antiretroviral therapy in Eastern Uttar Pradesh: a prospective study. Indian J Med Res. 2014;140:491-500. Medline:25488442

19 Ghate M, Deshpande S, Tripathy S, Godbole S, Nene M, Thakar M, et al. Mortality in HIV infected individuals in Pune, India. Indian J Med Res. 2011;133:414-20. Medline:21537095 
20 Rai S, Mahapatra B, Sircar S, Raj PY, Venkatesh S, Shaukat M, et al. Adherence to Antiretroviral Therapy and Its Effect on Survival of HIV-Infected Individuals in Jharkhand, India. PLoS One. 2013;8:e66860. Medline:23825577 doi:10.1371/ journal.pone.0066860

21 Ryavanki SP, Kosambiya JK, Mehta A, Dayama SO, Solanki N, Kantharia SL. General profile and survival probabilities of HIV patients registered at antiretroviral therapy (ART) centre, New Civil Hospital, Surat, Gujarat. National Journal Community Medicine. 2013;4.

22 Census. Andhra Pradesh Population Census data New Delhi, India: Office of the Registrar General \& Census Commissioner, 2011

23 NACO. Annual reports. New Delhi, India: National AIDS Control Organization (NACO), 2007-2013.

24 Cleves M, Gould W, Gutierrez R, Marchenko Y. An introduction to survival analysis using Stata. 3rd ed: Stata Press; 2010.

25 Kaplan EL, Meier P. Nonparametric estimation from incomplete observations. J Am Stat Assoc. 1958;53:457-81. doi:1 $0.1080 / 01621459.1958 .10501452$

26 Cox DR. Regression models and life-tables. J R Stat Soc B. 1972;34:187-220.

27 Ford D, Robins JM, Petersen ML, Gibb DM, Gilks CF, Mugyenyi P, et al. The impact of different cd4 cell-count monitoring and switching strategies on mortality in HIV-infected African adults on antiretroviral therapy: An application of dynamic marginal structural models. Am J Epidemiol. 2015;182:633-43. Medline:26316598 doi:10.1093/aje/kwv083

28 Namusobya J, Semitala FC, Amanyire G, Kabami J, Chamie G, Bogere J, et al. High retention in care among HIV-infected patients entering care with CD4 levels $>350$ cells/muL under routine program conditions in Uganda. Clin Infect Dis. 2013;57:1343-50. Medline:23899683 doi:10.1093/cid/cit490

29 The Opportunistic Infections Project Team of the Collaboration of Observational HIVERiEiE, Young J, Psichogiou M, Meyer L, Ayayi S, Grabar S, et al. CD4 Cell Count and the Risk of AIDS or Death in HIV-Infected Adults on Combination Antiretroviral Therapy with a Suppressed Viral Load: A Longitudinal Cohort Study from COHERE. PLoS Med. 2012;9:e1001194. Medline:22448150 doi:10.1371/journal.pmed.1001194

30 Hoffmann CJ, Schomaker M, Fox MP, Mutevedzi P, Giddy J, Prozesky H, et al. CD4 count slope and mortality in HIV-infected patients on antiretroviral therapy: multicohort analysis from South Africa. J Acquir Immune Defic Syndr. 2013;63:34-41. Medline:23344547 doi:10.1097/QAI.0b013e318287clfe

31 Lewden C, Gabillard D, Minga A, Ekouévi DK, Avit D, Konate I, et al. CD4-specific mortality rates among HIV-infected adults with high CD4 counts and no antiretroviral treatment in West Africa. J Acquir Immune Defic Syndr. 2012;59:2139. Medline:22027874 doi:10.1097/QAI.0b013e31823b837e

32 Bhaskaran K, Hamouda O, Sannes M, Boufassa F, Johnson AM, Lambert PC, et al. Changes in the risk of death after HIV seroconversion compared with mortality in the general population. JAMA. 2008;300:51-9. Medline:18594040 doi:10.1001/jama.300.1.51

33 Adamu BT, Wencheko E, Gesesew HA, Gebremedhin AT. Factors Associated with High Risk Mortality of HIV Patients Treated with Highly Active Anti Retroviral Therapy in South Western Ethiopia: A Retrospective Cohort Study. Public Health Research. 2013;3:169-77.

34 Alemu AW, Sebastian MS. Determinants of survival in adult HIV patients on antiretroviral therapy in Oromiyaa, Ethiopia. Glob Health Action. 2010;3. Medline:21042435 doi:10.3402/gha.v3i0.5398

35 Kee MK, Lee JH, Kim EJ, Lee J, Nam JG, Yoo BH, et al. Improvement in survival among HIV-infected individuals in the Republic of Korea: need for an early HIV diagnosis. BMC Infect Dis. 2009;9:128. Medline:19671189 doi:10.1186/14712334-9-128

36 Mageda K, Leyna GH, Mmbaga EJ. High initial HIV/AIDS-related mortality and -its predictors among patients on antiretroviral therapy in the Kagera Region of Tanzania: A five-year retrospective cohort study. Aids Res Treat. 2012;2012:843598. Medline:22973505 doi:10.1155/2012/843598

37 Bassett IV, Coleman SM, Giddy J, Bogart LM, Chaisson CE, Ross D, et al. Barriers to care and 1-year mortality among newly diagnosed HIV-infected people in Durban, South Africa. J Acquir Immune Defic Syndr. 2017;74:432-8. Medline:28060226 doi:10.1097/QAI.0000000000001277

38 May M, Sterne JA, Sabin C, Costagliola D, Justice AC, Thiebaut R, et al. Prognosis of HIV-1-infected patients up to 5 years after initiation of HAART: collaborative analysis of prospective studies. AIDS. 2007;21:1185-97. Medline:17502729 doi:10.1097/QAD.0b013e328133f285

39 Chan CW, Cheng LS, Chan WK, Wong KH. Highly active antiretroviral therapy per se decreased mortality and morbidity of advanced human immunodeficiency virus disease in Hong Kong. Chin Med J (Engl). 2005;118:1338-45. Medline: 16157027

40 Bedelu M, Ford N, Hilderbrand K, Reuter H. Implementing antiretroviral therapy in rural communities: the Lusikisiki model of decentralized HIV/AIDS care. J Infect Dis. 2007;196 Suppl 3:S464-8. Medline:18181695 doi:10.1086/521114

41 Chen M, Dou Z, Wang L, Wu Y, Zhao D, Gan X, et al. Gender Differences in outcomes of antiretroviral treatment among HIV-infected patients in China: A retrospective cohort study, 2010-2015. J Acquir Immune Defic Syndr. 2017;76:2818. Medline:28708809 doi:10.1097/QAI.0000000000001500

42 Damtew B, Mengistie B, Alemayehu T. Survival and determinants of mortality in adult HIV/Aids patients initiating antiretroviral therapy in Somali Region, Eastern Ethiopia. Pan Afr Med J. 2015;22:138. Medline:26889319 doi:10.11604/ pamj.2015.22.138.4352

43 Assefa T, Wencheko E. Survival analysis of patients under chronic HIV-care and antiretroviral treatment at Tikur Anbessa Specialized Hospital, Addis Ababa, Ethiopia. Ethiop J Health Dev. 2012;26:22-9.

44 Harrison KM, Song R, Zhang X. Life expectancy after HIV diagnosis based on national HIV surveillance data from 25 states, United States. J Acquir Immune Defic Syndr. 2010;53:124-30. Medline:19730109 doi:10.1097/QAI.0b013e3181b563e7 